on it of any decision regarding space research. There was, and would continue to be, great scope for international co-operation outside the Commonwealth in this field, and $\mathrm{Mr}$. Taylor referred particularly to the International Committee on Space Research, one of the fruits of the International Geophysical Year. It was also expected that an ad hoc committee of the United Nations could meet shortly to consider what international action regarding co-operation in the peaceful uses of outer space could profitably be taken at inter-government level.

\section{Manchester Literary and Philosophical Society: New Building}

THE foundation stone of the new building of the Manchester Literary and Philosophical Society was laid at 36 George Street-the site of the old building destroyed in an air raid in December 1940-by the Lord Mayor of Manchester, Alderman J. E. Fitzsimmons, on April 30, and it is expected that the new meeting house will be ready in about a year's time. In welcoming the Lord Mayor, the president of the Society, Mr. C. E. Young, said that the building destroyed in 1940 had housed the Society for at least 140 years. Before the building was acquired in 1799 the Society, which was founded in 1781, had met first in the Assembly Coffee House, which was probably in the Exchange Buildings of that day, and later in a room at the back of Cross Street Chapel. Mr. Young referred to the association with the Society of such famous scientists as Percival, Dalton, Joule, Schunck and Roscoe, among its past presidents, and afterwards, in a speech at an informal luncheon, expressed the hope that the Society would become a meeting place of minds from town, university and industry, representing and serving the everyday intellectual life of the city.

Thanking the Lord Mayor on behalf of the Society, Lord James expressed the conviction that there is even more important work for such a Society to do to-day. When it was founded and for the next halfcentury, an educated man could take all knowledge for his province. That is no longer possible, and one of our greatest needs is to encourage communication between men educated in different fields. Lord James thought the Literary and Philosophical Society could make a very important contribution to the establishment of channels of communication between specialists. By providing a formal and informal meeting place for people with widely differing interests, the Society was preparing to maintain and extend its original task of stimulating the intellectual life of the city. That task would call for the support and encouragement, financial and otherwise, of a considerable body of sympathizers. $\mathrm{Mr}$. Young referred particularly to the need for adequate financial support for operation and maintenance, although the membership of the Society is now 320 , the highest in its history. Virtually all the contents of the old centre were destroyed by fire, including the records, the library and Dalton's manuscripts and other relics, and there is a deficit of some $£ 10,000$ on the $£ 35,000$ which the new building will cost, to be met before the Society can be reestablished on a sound financial footing. It is hoped and expected that the lecture rooms will be used by many of the numerous scientific and other societies which are active in Manchester. Both Mr. Young and Lord James paid tribute to the work of the Society's honorary treasurer, Mr. H. Hayhurst, in promoting the scheme.
The Vienna Declaration and Nuclear Disarmament

The Vienna Declaration, adopted by the participants in the Third Pugwash Conference held at Kitzbuhel, Austria, on September 14-19 and at Vienna on September 20, 1958 (ef. Nature, 180, 358 ; 1957), has been sent, with a questionnaire and a letter signed by Lord Russell, to scientists all over the world to ascertain whether there is general support for the ideas expressed in the Declaration and for further activities based on it. The Declaration affirms that the only restraint against the use of nuclear weapons in war would be agreements not to use them, which were concluded in time of peace : the possession of such weapons is relatively unimportant, as in any future major war each belligerent would feel compelled to undertake immediate production of nuclear weapons, and for a major industrial power less than one year should suffice. The statement recognizes that any agreement on disarmament, and particularly on nuclear disarmament, requires a measure of control to protect every party from possible evasion, and because of the technical difficulties, the need for policies encouraging international trust and reducing mutual apprehension is stressed. The signatories believe that, as scientists, they have an important contribution to make towards establishing trust and co-operation among the nations, and that science can best serve man if it is free from interference by any dogma imposed from outside, and can exercise its right to question all postulates, including its own. The seientific tradition of mutual understanding and of international co-operation can, and should be, extended to many fields of technology.

\section{Quality of Protein Feeding-Stuffs}

Sir Solly ZUCKERMAN, a member of the Agricultural Research Council and chairman of its Protein Quality Group, writes: The Agricultural Research Council has organized a collaborative investigation into the measurement of the quality of protein feeding-stuffs. Several centres are taking part in a trial designed to establish whether any rapid laboratory tests can give a reliable indication of the feeding value of such materials. Specimens of these materials, some of which have been imported, were kindly supplied by manufacturers who have included, in response to a request to cover as wide a span of quality as possible, samples known to be bad, as well as samples within the commercial range. When it has been completed, the results of the whole trial will be published by the Committees as a whole. In the meantime, however, it is probable that members of the staff of the participating laboratories will be publishing in various journals papers describing work in which some of these samples have been used, but which deal with matters not directly related to the correlations which the joint effort is designed to elucidate. It has been agreed that in any such papers the samples used will be described by the code numbers uniformly used by the whole group.

\section{Australian and New Zealand Association for the Advancement of Science}

A REPORT on the future of the Australian and New Zealand Association for the Advancement of Science published in the Australian Journal of Science for October 21, 1958, advocates discontinuing the Handbook and Report and making greater use of the Australian Journal of Science, which it is proposed to publish monthly. Conferences every year and a half are recommended instead of annually or biennially. 